\title{
Working at Writing and the Question of Being
}

\author{
Lola Lemire Tostevin
}

\section{Le travail sur l'écriture et la question de l'être}

Celle qui écrit doit-elle écrire pour exister ou peut-elle tout simplement s'asseoir dans un jardin un après-midi d'été et paresseusement appréhender le monde? Observer les pivoines, le pied d'alouette inclinant sa tête langoureuse, la clématite, reine des vignes et pourquoi donc devrait-elle toujours penser en termes de métaphores, se demande-t-elle?

Quiconque a déjà écrit, précise-t-elle, sait à quel point la langue peut résister à l'intention. Mais elle refuse de s'abandonner à cette pensée laborieuse, préférant demeurer dans l'état de grâce qui accompagne la fin d'un roman qu'elle vient de terminer et préserver la sensation de légèreté quil'habite alors qu'elle observe les fleurs.

Bourdonnement des abeilles ouvrières guidées par le soleil. Peut-être son jardin abrite-t-il une ruche ou un nid d'abeilles? Sa méditation sur le caractère social du travail de ces insectes s'applique aussiau travail d'écriture, pourtant plus solitaire, pense-t-elle. Ont-elles aussi la crainte stupide de perdre du temps? La grâce léthargique des mouvements de l'abeille la saisit en tout cas, tandis qu'elle fait soigneusement, posée sur l'accoudoir d'un fauteuil, la toilette de ses antennes. Comme l'œil complexe de l'abeille bouge en même temps que des millions de choses minuscules, l'écrit déforme et amplifie lui aussi.

Celle qui écrit, tirée qu'elle est vers le langage, sait que le langage dessine toujours ses propres motifs, alors qu'elle s'enfonce dans la beauté du paysage.

"Where word breaks off no thing may be."

$$
\text { Stefan George }
$$


As she sits in her garden on a summer afternoon, the writer thinks about the function and meaning of the verb to be in relation to writing. Must a writer write in order to be? Or can a writer just sit in a garden on a summer afternoon and lazily apprehend the world?

Listless, relieved to have finished at last a novel she's been working on for three years, all the writer wants to experience at the moment are the peonies; larkspur arching its languorous head, testing the air; clematis, queen of the vines, swooning like long-throated women in shredded wedding lace. Why must she always think in metaphors, the writer asks herself. She's been cautioned over and over again about the fraudulence of comparisons.

Yesterday, a member from the editorial collective of TESSERA telephoned to invite the writer to contribute a piece for the next issue which will focus on "work" as its main subject. The writer is invited to explore the concept of work as an attempt to embody intention in a resistant medium where there is always counterforce. Such as language, the writer thinks. Anyone who has ever written knows how resistant language can be to intention.

The writer considers the editorial collective's request and concludes that writing about resistance is precisely what she doesn't want to do on a summer afternoon. Doesn't want to work, doesn't want to write about work, doesn't want to even skirt the subject. She simply wants to sit in the garden and enjoy the state of grace that follows the end of a project. If she ever writes anything again it will be to re-experience this feeling of light, of lightness, when watching flowers push skyward from the earth.

The sun is glorious, the trees and birds mutter in the blue air, the writer sips on lemonade and lets herself drift in and out of empty rest. Burrows herself into the cushion of her lawn chair, remembers a line from her novel and smiles. Her main character yearning to mold herself to a shell like a snail. The coolness of that image, of mother-of-pearl. 
She is thinking of this and what she would write if she were to accept the invitation from the editorial collective when she notices all around her the sound of bees. An immense buzzing of bees, electric with solicitation. The sound of choreography moving in relation to the sun to convey to the rest of the colony where to find pollen and nectar. Worker bees sucking up sweetness with long tongues, storing it inside their bodies, packing pollen into little baskets on hind legs. The sound of worker bees as each one orbits her nucleus of being.

The writer looks around her trying to locate where the bees are coming from, if her garden shelters a hive or a nest. Compared to writers, honeybees are such social insects, the writer thinks, the hive a marvel of insect life. The queen, the drone, the worker, each one assigned a place within an order, each one using its talent and time in precision to other bees. It is the other - queen, worker, drone - that teaches each bee who she is and how to be. The writer rests her cheek against the frosted glass of lemonade.

Being-for-Others is what one philosopher called it. Being-for-Others, the very condition of the hive's survival, each bee's function programmed, her instinct intact: when and how to build honeycombs; when the developing bees need food; when to start a cell in which to raise a new queen; when to kill the burly, clumsy drones or sting to death an intruder mouse. It even knows when and how to air condition the hive to keep it cool or warm. The hive being the natural habitat of the function of inhabiting and being.

The writer read once that the enterprise and skill with which bees make and maintain their hives is so efficient that it surpasses the ability of masons, carpenters, builders. There is a proverb which says that man -or woman - can build almost anything except a bee's hive. Or is that a bird's nest? The writer is not sure of her facts. Unlike the bee, the writer's instinct is not intact nor is her knowledge unerring. While the bee's work is sufficient to itself and to its order there exists at the basis of human life a principle of uncertainty, of insufficiency. 
There rages around the garden the unbridled sound of bees buzzing around larkspur, peonies and clematis. The sound of buzzing rising, impatient, feverish. It is the sound of obsession. The stupid fear of wasting time. The writer takes another sip of lemonade. If she accepts the invitation she'll be offering once more her insufficiency to scrutiny, criticism, approval. Categorizing, classifying words in relation to someone else's expectations - a school, a fashion, a theory- like a species to its genus.

She could write about the sufficiency and essence of worker bees versus the insufficiency of writers. At least as much as language can convey essence. Worker bees in search of substances that generate their own unctuous body-substance. She could pretend, if only to herself, to capture the essence of honey while knowing full well that she will only be taking on another project to which her insufficiency condemns her. The forging of metaphors and similes that resist and protect their own essence like a bee protecting its hive from an intruder mouse. Knowing full well that it is the writer's subversion to this relation of resistance that drives her to frustration and rebellion. Drives her to sit in her garden vowing never to write again.

She could sit here for the rest of the summer and leave unspoken whatever comes to mind about work and flowers and bees. Do nothing but sip lemonade. Like a tick on a branch of that tree over there. Inert, waiting patiently for months on end for some warm-blooded animal to walk by so it can drop and burrow itself into something vascular. That's the tick's job. All it knows and wants to know of the garden is warm blood.

Suddenly, a bee materializes from the writer's bonnet, traces invisible circuits around the writer's head and comes to rest on the arm of the lawn chair. She observes the lethargic grace of the bee's movements as it cleans with its front legs and spurs the dirt and pollen from its antennae, its tongue an instrument of exploration. Each antenna twitching as if picking up signals, the bee's body responding to gestures and operations of a code fixed in its own meaning, its own being. Its body covered with hair. 
On either side of the bee's head a compound eye, made up of thousands of single eyes, moves in relation to a million other infra-things. Eyes smaller than the head of a pin summoned by the magnified distortions of flowers and trees. Eyes drawing their own designs, their own conclusions.

Far from seeing clearly, writing also distorts and magnifies. The writer drawn to language, aware that language always draws its own designs but also aware that its sufficiency or insufficiency is irrelevant. Only in words can the writer apprehend what buzzes around her and in her head. Only in the word "work" does she hear and see what is being worked, its relevancy consisting in its having been written whether it captures or not the essence of anything other than itself. Words - the natural habitat of the function of inhabiting and being.

The writer will accept the editorial collective's invitation after all and write about how, in language, the garden spreads into grass, trees, rocks. Rises toward the bloom of sky, toward a vaulting path for the sun and the changing moon. Clouds drifting through blue depths of light and dusk, through the clemency and inclemency of weather, through seasons. It is in writing that the mouth flowers. The magnified distortions of larkspur, peonies, clematis. The diaphanous wing-beats of the bee. Of the mind and of the heart. 